\title{
'Police boys' and poachers: Africans, wildlife protection and national parks, the Transvaal 1902 to 1950
}

\section{JANE CARruthers}

Carruthers, Jane. 1993. 'Police boys' and poachers: Africans, wildlife protection and national parks, the Transvaal 1902 to 1950. Koedoe 36(2): 11-22. Pretoria. ISSN 0075-6458.

\begin{abstract}
The concentration on pure scientific research in the Kruger National Park has resulted in a neglect of a humanistic approach to nature conservation issues. The lack of human and political dimensions in important scientific contributions are serious short-comings in the light of present politico-environmental concerns. The impact of race and class on wildlife protection needs to be integrated. Scientifically sound but culturally chauvinistic protectionist strategies have been imposed upon disadvantaged African communities unable to articulate or formulate alternatives. African participation has usually either been ignored or relegated to patronizing and oversimplified accounts of Africans in the roles of 'native rangers' or 'poachers'. This police-poacher view is countered by an over-simplified African perception of national parks as being of benefit only to elitist white recreation. These divergent perceptions have important implications for the future of nature protection in South Africa.
\end{abstract}

Key words:

Jane Carruthers, Department of History, University of South Africa, P.O. Box 392, Pretoria, 0001 Republic of South Africa.

\section{Introduction}

The most significant development in the philosophy of natural resource protection to have occurred in recent decades has been the shift away from pure science towards a more humanistic approach. The world conference at Rio de Janeiro has provided tangible demonstration that nature protection today is coupled to and directly influenced by politics, culture and economy.

Differing opinions on these issues were well represented in Brazil as experts in almost every discipline assembled to debate the current and future well-being of the planet. It is noteworthy that historical analysis played little part in the Rio proceedings. This is a considerable deficiency, and although there are indications of change in South Africa, the academic contribution has so far been limited.' Some South African universities take account of the natural environment in certain history courses, but environmental history is far from being the vigorous field of specialisation it is, for example, in the United States. Historical works aimed at the general reader are more numerous but superficial.

The meagre historical output must be contrasted with the enormous body of scientific literature directly and indirectly related to nature protection in South Africa. There are well-funded and wide-ranging investigations at the level of universities, technikons, museums and the Foundation for Research Development, into issues such as taxonomy, wildlife and veld management, ethology, wildlife veterinary science, ecological studies, pollution, population dynamics or water and soil conservation.

The lack of human or political dimension in these important scientific contributions is a serious short-coming in the light of present politico-environmental concerns. The impact of race, class and the issues raised by postmodernism on wildlife protection need to be integrated into scientific studies and a freeflow of information between disciplines de- 
veloped. The core political philosophy in Africa which has realigned the nexus between humans and the natural environment in modern times has been colonialism. In the field of formal nature protection scientifically sound but culturally chauvinistic protectionist strategies have been imposed upon disadvantaged African communities unable to articulate or formulate alternatives.

In the popular South African literature, African participation has usually either been ignored or relegated to patronising and oversimplified accounts of 'courageous and loyal native rangers' or 'evil, cruel poachers'. This police-poacher view is countered by an over-simplified African perception of nature protection as being of benefit only to elitist white recreation. ${ }^{3}$ The impulse behind this paper has been to employ archival sources to analyse these stereotypes more closely, using the interface between the Sabi and Singwitsi Game Reserves (later combined into the Kruger National Park) and affected African groups. Although scanty and biassed from a white point of view, surviving primary material makes it clear that the African presence is in many ways all-pervading. Indeed, its influence - or its perceived influence - has been a crucial determinant in shaping wildlife legislation in South Africa.

Why have Africans, with a far longer relationship with the southern African environment, been 'written out' of colonial nature protection rather than co-opted into it? Like all legislation, nature protection reflects the view of the dominant classes. As wildlife resources diminished, competition grew and restrictions were increasingly imposed upon Africans, whose subsistence way of life was considered inimical to early white protectionist aims, i.e. the market and sport. As the state increasingly came to dominate protectionism and as western conservation principles and practice underwent major changes, Africans were generally regarded as irrelevant even to the new issues of aesthetics, tourism and scientific investigation and thus marginalised further.

\section{Wildlife conservation legislation in the Transvaal to 1902}

In pre-colonial times the rich wild fauna of the sub-continent was depended upon for survival and material well-being. Evidence from East Africa indicates that conflict typified the historical human-wildlife relationship and that a frontier situation existed between wilderness and the ranges and fields of expanding agro-pastoralists. ${ }^{4}$ There are no firm grounds for believing that the South African experience was substantially different, although there is fragmentary evidence of 'wise use' or conservation among huntergatherers and the reservation of scarce species for royalty or totems among Bantuspeaking communities. Evidence of prosperous trading networks and undisputed prowess with firearms and sophisticated agricultural technology once these were introduced, suggests that technological restraints and lack of markets were the principal pre-colonial limitations to environmental destruction.

With increased access to markets, firearms and steel cable for snares, came another colonial characteristic, formal wildlife protection legislation. Injunctions against killing non-human species do not - even today carry strong moral, cultural or legal weight and legislation was consequently powerless to prevent destruction. For some years after Voortrekker settlement of the Transvaal, the economy depended on indiscriminate wildlife hunting. While co-operation between indigenes and whites in the sphere of wildlife had previously been limited to bartering activities, collaboration in killing reached its apogee at Schoemansdal and the Voortrekker community and the African polities in the region consequently prospered. ${ }^{5}$

It was when this mutually advantageous partnership degenerated into a power struggle over the diminishing herds that whites felt sufficiently confident to exclude their collaborators from the trade. ${ }^{6}$ Early legislation restricted African access to free-ranging wildlife. ${ }^{7}$ Then, as African resistance to colonisa- 
tion was gradually broken, a landholding elite emerged and a new arm of wildlife protection was initiated. Because the legal status of wildlife is res nullius ${ }^{8}$, private landowners strictly enforced trespass regulations as a device by which to prevent Africans and poor whites from hunting. ${ }^{9}$ Despite combined conservationist and preservationist measures game preserves, closer regulations on hunting, closed seasons, prohibited species, gamekeepers and licence fees - Transvaal protectionist efforts had failed by the turn of the century.

The blame for exterminating the wildlife of the Transvaal was laid upon Africans. With hindsight it can be appreciated that the most consequential destructive influences relate to the agricultural transformation of the countryside and to the modernization and industrialisation of the Transvaal. But in addition to these broader processes, it seems that even white market hunters and sportsmen killed more than did Africans at that time. Abel Erasmus, renowned for his harsh treatment and unyielding hostility to Africans, was one who appreciated that whites were far more destructive than Africans. ${ }^{10}$ They were subject to far harsher legal limitations than whites, for they did not share the hunting privileges of landowners, nor did they have legal access to firearms (clandestine trapping is not an efficient method for killing in large numbers). In addition, Africans were not eligible for hunting licences, able to kill wildlife damaging their crops and their ownership of hunting dogs was curtailed. Possibly in consequence, within African 'locations' plenty of wildlife survived, and there were even reports of active African conservation intervention at the turn of the century. ${ }^{11}$

In many instances, therefore, the African target provided a convenient and morally acceptable excuse for whites in order to keep the wildlife resource solely to themselves. White vituperation against African hunting was based on the European ideology that to subsist on game was 'less civilized' than to sell it or to kill it for entertainment. There was also the abhorrence of African methods of hunting which were increasingly regarded as 'cruel'. But by the end of the nineteenth century the materialist underpinnings of wildlife protectionism had become quite evident: 'the destruction of game by the natives ... enables a large number of natives to live by this means who would otherwise have to maintain themselves by labour'. ${ }^{2}$ Wildlife protection thus played a role in creating a proletariat as the industrialisation of the Transvaal began at the turn of the century.

\section{Re-creating Eden? Game reserves and national parks}

As the once abundant herds of wildlife diminished changes in wildlife protectionism in the Transvaal altered from market considerations to those of sport hunting. It was at the turn of the century that game reserves became a formal and well-managed state preservationist measure.

Often no distinction is made in the literature between game reserves and national parks. What both game reserves and national parks have in common is state control over, or nationalisation of, certain natural resources. Game reserves preceded national parks chronologically and, although today their goals may overlap to some extent, they have had a different aim and legal basis. The purpose of a game reserve was to provide, free from all human interference, a sanctuary in which certain species of wildlife could prosper. In the Transvaal, they were insecure institutions for they could be established or abolished merely by proclamation. A national park, by contrast, is a state conservationist measure, legally secure and economically viable, which entails utilisation of an area through active management for the benefit of the ecosystem and visitors, whether for educational or recreational purposes. Different strategies were therefore needed to accomplish the different goals of game reserves and national parks. The principles and organisation of protectionist land use have therefore not been static and the status of protected land in South 
Africa has evolved in response to changing political and economic impulses.

South Africa's first national park was established by the Union parliament in 1926 in an area which had comprised two provincial game reserves in the eastern Transvaal, the Sabi (founded 1898) and the Singwitsi (founded 1903).

In 1902 the purpose of the re-proclaimed game reserves in the Transvaal was to set aside what was considered at the time to be disease-ridden, agriculturally and minerally worthless land to provide a state sanctuary (or a nursery) in which stocks of game, i.e. huntable wildlife, could recoup their numbers having been decimated before and during the South African War. ${ }^{13}$ The game reserves were thus not 'Gardens of Eden' or tourist attractions but state game farming enterprises. The ultimate aim was to open these game-rich islands in later years to sportsmen who would pay the state for hunting privileges. Until such time that this form of land use could become practicable, human use of the wildlife resource was outlawed altogether and no person was permitted entry to the game reserve. In order further to protect sporting quarry, wildlife management techniques comprised the vigorous extermination of 'predators' and 'vermin' (all raptors, certain reptiles, lion, cheetah, jackal, hyena, wild dog, bushpig and others). Because there was no systematic ecological discipline at the time, the physical landscape did not receive active protection and fire control, eradication of exotic vegetation etc. was lacking.

With the re-establishment of the game reserves government administration was imposed upon the eastern Transvaal lowveld for the first time. It was this, more than the protectionist measures, which impinged on and altered African life in the area. The major points of intersection between Africans and officials in charge of the game reserves were in respect of land, labour and poaching.

\section{Labour and land}

In 1902 it was estimated that there were about three thousand people living in the Sabi Game Reserve. ${ }^{14}$ James Stevenson-Hamilton, the first warden, was a Scottish landowner with a traditional European belief that people and game preserves do not mix. Thus, following instructions from the Native Affairs Department (in whose jurisdiction the game reserves initially fell), one of his first actions was to evict Africans from the game reserve. He anticipated a co-operative response ${ }^{15}$ but within months was accused of forcing people to move out. ${ }^{16}$ StevensonHamilton's actions gained him the name 'Skukuza' (he who sweeps clean) and bequeathed to the game reserve the reputation among local communities that 'the government wants to drive [us] away from the low veld so as to include these parts in the game reserve'. ${ }^{17}$

But despite the assertion in a popular account, that Stevenson-Hamilton had removed 'all the black squatters ... settling them closer to their traditional tribal chiefs in adjacent areas, ${ }^{18}$ the reserve did not lose its resident African communities. On the contrary, when the Sabi Game Reserve was extended from the Sabie to the Olifants River in August 1903 by including private and crown land, and when the Singwitsi Game Reserve (crown land between the Groot Letaba and the Luvuvhu Rivers) was declared in May 1903, more people were incorporated. They did not have to vacate their homes because the colonial authorities had only taken a year to appreciate that the extensive Transvaal game reserves could not be run like a medieval European deer preserve. Africans could assist the protectionist endeavour by providing both labour and funding and thereby ensure the success of the re-stocking programme. ${ }^{19}$

Consequently, the policy of removing Africans from the game reserves was reversed. After May 1905 the almost three thousand residents, like other tenants on crown lands, were subject to the payment of rent either in 
the form of cash or labour. ${ }^{20}$ The three-month compulsory labour period for the approximately four hundred due-paying tenants proved extremely profitable as did rents in cash. ${ }^{21}$ Tenants were, in exchange, permitted to conduct agricultural and pastoral activities within the boundaries of the reserve (possible because of the disappearance of the tsetse fly from the lowveld after the rinderpest epidemic of 1896), provided that wildlife regulations were not infringed.

Like all tenants on crown lands, this control was resented by people living in the game reserves. They would often 'disappear' when their labour was being sought ${ }^{22}$ On the other hand, game reserve labour seems to have been less onerous than farm labour and the reserve was accused of providing a refuge for those avoiding it. ${ }^{23}$ White game rangers usually people who preferred isolation and disliked human contact - felt that overseeing tenants made for additional work, in that they had to listen to 'troubles and indabas', but accepted it because it had the advantage of consolidating control over them. ${ }^{24}$

The number of tenants did not remain constant. Because the eastern Transvaal lowveld is not agriculturally rich, in difficult years many tenants left to seek employment elsewhere, and an outbreak of foot-and-mouth disease in 1939 destroyed the livestock of the majority of tenants and a mass exodus ensued. $^{25}$

Prison labour supplemented the tenant labour workforce. The system which seems to have operated was that illegal immigrants from Mozambique seeking work on the Transvaal mines were either arrested by game reserve officials or reported themselves as trespassers, which resulted in a fortnight's imprisonment. ${ }^{26}$ When the sentence had ended, the men (about one thousand each year) were given a 'pass' - permission which entitled them to seek employment in the Transvaal. ${ }^{27}$

The reserve officials did not incarcerate illegal immigrants, most of whom did not wish to flee and regarded the fortnight's labour - usually on road-making - as an exchange for their 'pass'. ${ }^{28}$ This casual treatment of offenders was deplored by the Departments of Justice and Native Affairs, which insisted that all prisoners be taken to Sabi Bridge (now Skukuza) for formal detention. ${ }^{29}$ A commentator of the time, sympathizing with the labour requirements of the game reserves, declared this to be mere 'idleness at the expense of the government ... a foolish arrangement and very unpopular with the natives. ${ }^{30}$ In 1924 the problem was partially solved to the satisfaction of the game reserves by the introduction of 'movable lock-ups', transportable prison cells which could be moved around the reserve wherever labour was needed. ${ }^{31}$ Despite a period around 1926 when an immigration treaty between Mozambique and South Africa disrupted the flow of trespassers, the transport and construction infrastructure of the game reserves until fairly recent decades depended significantly on prison labour. ${ }^{32}$

The labour situation within the game reserves has been overlooked in popular accounts. Can this be explained by the strength of the white romantic myth which has come to infuse nature protection literature? One popular account describes the labour situation as follows: 'There were eight rangers, each with a small number of black assistants to do the work; build roads, build huts, keep a vigilant eye on the never-ending bands of poachers, and patrol a wilderness area larger than the state of Israel. ${ }^{33}$ Such statements pander to the sentimental and obscure the labour foundation upon which the protectionist effort has been secured.

Not all African labour was coercive and there were paid African officials as well. The first employees of the Sabi Game Reserve - apart from the warden - were black. There was 'Toothless Jack ... an old hunting boy' who knew the district well and four other men who were proficient with horses. ${ }^{34}$ As the organisational structure of the game reserve took shape, an important category of African 
worker was the 'native police' force, which in 1941 consisted of eight sergeants (one in each section) and about 120 African rangers. ${ }^{35}$ These men were generally recruited from the local resident community, being familiar with the terrain and its inhabitants. Their relationship with the game reserve was a complex one of co-operation and resistance. Available evidence suggests that the police usually collaborated with their white superiors - even to the extent of informing on their relatives. ${ }^{36}$ But there were instances of overt resistance, most often in the form of poaching or dereliction of duty. ${ }^{37}$ Although the records reflect interaction between the different squatter communities only tangentially, the 'police' may have exploited their positions by targeting unpopular individuals or groups. Collusion between white and African rangers also occurred, as in 1941 when poaching and dagga production by African police was not reported to the National Parks Board in Pretoria, since the white staff was reluctant to dismiss some of their most efficient trackers and protectors. ${ }^{38}$

Although the cult of the heroic individual typifies protectionist literature, the encounter between game ranger Harry Wolhuter and a lion being prominently depicted in popular accounts and in the Skukuza museum for example, African employees who devoted themselves to wildlife protection, or even gave their lives for it, having been killed by wild animals or by poachers, have not received the same degree of public acclaim. Stevenson-Hamilton privately expressed his admiration for the sense of duty demonstrated by African rangers given their poor pay and lack of incentives. ${ }^{39}$ However, as was customary throughout colonial Africa at the time, 'police boys' were never promoted into the higher ranks of the white rangers. It is not yet fully understood in what terms African rangers perceived their protectionist role and a close examination of the individual careers of African rangers would yield fascinating insights.
The inter-connection between land and labour extends into land appropriation which was a frequent point of dissension, although less frequently among African interests than those which were white or state-controlled. After Union in 1910 the supposed 'worthlessness' of game-reserve land and the desirability of a state game nursery were reviewed. The deleterious effects of disease were less threatening than they had been in 1902, and this led to demands in many quarters for the abolition of the game reserves. Land was needed to provide for additional African and white agriculture, mining and industry. As far as African land was concerned, the Native Affairs Administration Bill had suggested the Singwitsi Game Reserve as suitable for future African settlement. The Transvaal Provincial Commission of Inquiry of 1918 (which was instituted to investigate the proposed national park) raised the issue but gave it short shrift, considering the Singwitsi unsuitable for any prolonged human habitation. ${ }^{40}$ The inhospitable landscape of the north thus remained a protected area. However, as a result of pressure from the Native Affairs Department in 1923 , before the proclamation of the national park occurred, a large area was excised from the southerly Sabi Game Reserve (in the Acornhoek district) on its western boundary for an African 'reserve'.

The borders of the national park remained substantially unaltered from 1926 until 1969 when a long-standing and acrimonious battle between the National Park authorities and the Makuleke community in the north ended. ${ }^{41}$ This Tsonga group, living at the confluence of the Luvuvhu and Limpopo Rivers, had in the nineteenth century had a large hand in the ivory trade of the district and later subsisted on hunting, agriculture and fishing. ${ }^{42}$ While scattered squatters were acceptable to game reserve officials, settled or expanding communities conflicted with protectionist aims, and in 1912 several Makuleke villages under Mhinga in the northern part of the Singwitsi were excised, thus reducing the game reserve area. $^{43}$ 
But owing to the scarcity of rangers in the north, the Makuleke community in time spilled into the game reserve zone. Officials regarded the whole area as a 'danger spot', and in the early 1930s the proposal was put forward by the National Parks Board to include the tropical forest between the Luvuvhu and the Limpopo Rivers within the park boundaries. The plan was to remove the Makuleke to land further south which would be excised from the park for this purpose. Moving the Makuleke was not, however, a simple matter because the Native Affairs Department refused to give its permission. Matters were complicated by other schemes for replacing the Makuleke by poor white settlers rather than increasing the size of the national park. $^{45}$

In order to circumvent the Native Affairs Department, the National Parks Board approached the more amenable provincial authorities which, in 1933, declared the district to be the Pafuri Game Reserve but placed it in the control of the National Parks Board. Makuleke's 'location' was surrounded by this reserve, although excluded from it. ${ }^{46} \mathrm{~A}$ stalemate followed because the Native Affairs Department continued its opposition. ${ }^{47}$

The issue caused a rift within the National Parks Board when the secretary, H.J. van Graan, pleaded with Board members: 'Is it wise to take this step in view of the reputation of the alleged suppression of native races? It is obvious that Pafuri is better agriculturally than the dry piece of grazing land we offer in exchange ... frankly, I foresee in this gain of today, if we acquire the Pafuri, the future germ of destruction of the whole Park. ${ }^{48}$ Van Graan was ignored and the impasse continued until 1952, when the Board returned the Pafuri Game Reserve to provincial control, explaining the situation as unworkable. ${ }^{49} \mathrm{In}$ the era of 'grand apartheid', in 1969 Makuleke and his people were re-located to the Ntlaveni area which had been excised from the Kruger National Park for their use. At that date, the Pafuri Game Reserve was incorporated into the park. ${ }^{50}$

\section{Poaching}

In the past, nature protection has often been regarded as a simple contest between the forces of 'good' and 'evil'. Upper and middle class European values such as the acceptability of shooting for sport and the condemnation of the cruelty of snaring for food were imposed on Africans. Their values were the opposite: killing for sport was wasteful and snaring was appropriate utilisation of a natural resource. Within the game reserves, the killing of any game species was punished ruthlessly. The tasks of game rangers at that time had little to do with scientific observation or environmental management, but revolved totally around their function as security guards for the game. To increase state herds was the sole purpose for the early existence of the reserves which would become valueless and collapse if they failed in this regard.

It is in this context that the conflict over access to wildlife resources between game reserve officials and Africans must be seen. Dominant white attitudes at the turn of the century can be measured by the outbursts of the Transvaal Game Protection Association, the members of which resented any wildlife killing other than for sporting purposes. ${ }^{51}$

Suspected poachers in the game reserves frequently resisted arrest, which was not surprising in view of the severity of the punishments they could receive. ${ }^{52}$ Punishments were inflicted on youths who caught cane rats and tortoises and chasing lion off a kill was also regarded as a poaching offence. ${ }^{53}$ Often hunger was the impetus for defying the game reserve regulations. Poaching can be directly related to seasons of drought, such as in $1913 .^{54}$ By 1918 the continuing food shortage, possibly coupled with the realisation that the number of white staff in the reserve had been reduced due to the First World War, encouraged Africans in the reserve, particularly those south of the Letaba River, to embark on what A.A. Fraser, then acting warden, called 'a wave of insubordination'. 
'conservation' - sustainable land use by visitors.

Important though these changes in philosophy were, the Kruger National Park - as its name indicates - was established in 1926 in direct response to political impulses. Success was due to the general adoption by whites of the philosophy that viewing and studying wildlife constituted a legitimate - and financially viable - form of land use and that state land should be allocated for this purpose. Other circumstances which coincided to make the national park a reality included the nascent rise of Afrikaner nationalism, the consolidation of a Voortrekker mythology and the search for a unified white South African national identity.

In breaking white resistance to wildlife protection and coalescing the different white factional attitudes, the new national park ideology reinvigorated the exclusion of Africans and consolidated the process of co-opting wildlife protection within the orbit of white culture. Within decades, the national park was being overtly exploited to exemplify and inculcate white South African culture, ${ }^{64}$ including casting blacks homogeneously in the role of poachers and whites in the role of conservationists.

Because after 1926 the Kruger National Park was integrated into the political economy of South Africa it could no longer operate - as the game reserves had done - in isolation from the rest of the country. New techniques were introduced in terms of administration, wildlife management and tourism. Until the park was opened to tourists in the late 1920s there had been no visitors at all and Stevenson-Hamilton, who considered tourism to be 'vulgarising' nature in any event, would probably not have objected to African tourists. But under the National Parks Board of Trustees, the warden did not have a free hand, and visitor access for blacks was - until very recently - on an unequal basis in terms of accommodation and recreational facilities. ${ }^{65}$
Throughout the 1930 s and 1940 s careful political appointments by the state to the nominally independent National Parks Board increased its politicisation. The extent to which it became a government agency can be gauged by an inquiry instituted in the early 1950 s which accused it of having replaced nature conservation with its political aim. ${ }^{66}$ This can be observed as early as 1932 when Board member Gustay Preller recorded his distress that Indians were using the same camp as whites, an incident which Stevenson-Hamilton dismissed tongue-in-cheek with the comment that he had thought that they were Portuguese. ${ }^{67}$ Later in 1949 when J.G. Strydom (the Minister of Lands in whose portfolio fell all national parks) addressed the Board on apartheid, he regretted not only that different race groups shared camps, but that they even shared the roads. Strydom advocated the dismemberment of the national park and that a portion be set aside for exclusive 'non-white' use. ${ }^{68}$ After the Second World War when recreational objectives were superseded by educational concerns, African visitors did not receive the same welcome as did whites and nor was any educational literature targeted at that market. Their formal exposure to the ecological value of modern protectionism thus restricted.

\section{Conclusion}

Although Africans had no direct hand in lawmaking in the early twentieth century Transvaal, white perceptions (real or imagined) that Africans destroyed vast numbers of wildlife, that they trespassed in order to do so, that they killed in a cruel manner, that they spoilt the recreation of sportsmen and managed to evade wage labour by subsisting on wildlife, were important determinants in shaping the protectionist ethos.

In addition, within state game reserves and national parks the African experience of nature conservation either meant removal or, as tenants on crown land, the provision of labour or rent. Although the financial benefits of a national park are considerable in terms of 
eco-tourism and infrastructural development, the costs and benefits are not equally borne by all the parties involved and benefits have largely by-passed impoverished neighbours.

Many long-held principles of conservation are now being re-evaluated and they may be informed by an historical analysis of the past. After centuries of ignorance, western conservation is being enriched by the indigenous African tradition, an input long excluded from the imported conservation ethic. The alienation of the majority from protectionist ideas is changing with more public participation in conservation strategies as well as education in their underlying principles. Such steps are now coming to be appreciated as being vital to any success. The notion of exclusive use, for example, is also under review and no longer considered vital to successful conservation. In addition, the continuous and extensive official culling of wildlife populations which exceed the restricted carrying capacity of many parks has brought the issue of utilisation of wildlife into question and the feasibility of people who live nearby benefiting from surplus wildlife has arisen. $^{70}$

During the twentieth century in South Africa the interface between culture and nature has been transformed for all human communities. In particular, cultural conflicts have been exacerbated by imbalances of power and public participation which have impinged directly on state efforts at nature protection.

\section{Source list and references}

1. A few examples are: Journal of Southern African Studies, 15(2), January 1989; E.J. Carruthers, 'Game protection in the Transvaal, 1846 to 1926', $\mathrm{Ph}$.D. thesis, University of Cape Town, 1988; D. Anderson and R. Grove, Conservation in Africa: People, Policies and Practice (Cambridge, 1987); $\mathrm{S}$. Trapido, 'Poachers, proletarians and gentry in the early 20th century Transvaal', Seminar paper presented to the African Studies Institute, University of the Witwatersrand, March 1984.

2. KNP [Kruger National Park Archives, Skukuza] Annual Report of the National Parks Board, 1931, p.2; R.J. Labuschagne, 60 Years Kruger Park
(Pretoria, 1958); H. Wolhuter, Memories of $a$ Game Ranger (Johannesburg, 1976); U. de V. Pienaar, ed., Neem Uit die Verlede (Pretoria, 1990).

3. See E. Koch, D. Cooper and H. Coetzee, Water, Waste and Wildlife: The Politics of Ecology in South Africa (London, 1990), p.17.

4. R. Yaeger and N.N. Miller, Wildlife, Wild Death: Land Use and Survival in Eastern Africa (State University of New York Press, 1986), pp.10,31, 66.

5. For a detailed explanation of the workings of the hunting state, see the chapter by R. Wagner in S. Marks and A. Atmore, eds., Economy and Society in Pre-Industrial South Africa (London, 1980).

6. For a detailed study of game protection in the Transvaal, see Carruthers, 'Game Protection in the Transvaal'.

7. Of the nineteen articles in the 1858 resolution (the first Transvaal legislation which can be regarded as having protectionist implications) thirteen were designed to curtail African hunters, disarm them, suppress their power and control their movement. Evidence abounds for whites flouting the 1858 law, and it is therefore intriguing that what may be the only record of voluntary observance of the hunting laws has come from Michael Buys, the leader of a half-caste clan. The author of the testimony may have been biassed in Buys's favour but the fact that Buys declared that he hunted only sufficient for his needs and was aware of the existence of hunting regulations makes the source of interest; S. Hofmeyr, Twintig Jaren in Zoutpansberg(Cape Town, 1890), pp.74-75, 120121.

8. There have been numerous attempts to change the legal status of game to that of domestic stock, so far without success.

9. Index der Staatscouranten over de Jaren 1857 tot en met 1870 (Pretoria, 1897) and Index der Staatscouranten over de Jaren 1871 tot en met Julie 1881 (Pretoria, 1898).

10. TA SS 1875 R3068/89, Erasmus to Superintendent of Natives, 22 September 1890. For a recent appraisal of Erasmus's career see P. Delius, 'Abel Erasmus: power and profit in the Eastern Transvaal' in P. Delius and W. Beinart eds, Putting a Plough to the Ground: Accumulation and Dispossession in Rural South Africa, 1850 to 1930 (Johannesburg, 1986).

11. TA SS302 R3130/78, Letter to Administrator, 31 August 1878; TA Minutes of the Volksraad, Article 674, 3 July 1894.

12. TA CS396 10370/03, TGPA to Colonial Secretary, 18 November 1903; J. Stevenson-Hamilton, 'Game preservation in the Transvaal', Blackwood's Magazine, March 1906, p.409.

13. The Pongola Game Reserve was one of these and failing in its purpose, it was neglected from about 1905 and abolished in 1921; see E.J. Carruthers, 'The Pongola Game Reserve: an eco-political study', Koedoe 28, 1985, pp.1-16. 
14. TA SNA169 NA2063/03, Report on the Sabi Game Reserve for the year ending August 1903.

15. TA SNA52 NA1904/02, Stevenson-Hamilton to Lagden, 4 September 1902.

16. KNP Stevenson-Hamilton Documents in Trust, Reports by ranger Gray, 1-7 October 1902 and 5-12 November 1902; TA SNA169 NA2063/03, Report on the Sabi Game Reserve for the year ending August 1903; TA SNA50 NA1751/02. Stevenson-Hamilton to McInerney, 18 August 1902: Native Commissioner Lydenburg to Secre. tary for Native Affairs, I8 November 1902.

17. TA SNA32I 1321/06, F. Steinacker to Secretary for Native Affairs. 4 April 1906; Cent. [Central Archives, Pretoria] NTS 7612 9/329, Chief Native Commissioner to Secretary for Native Affairs, 11 November 1946.

18. L.E.O. Braack. The Kruger Narional Park (Cape Town, 1983), p.12.

19. J. Stevenson-Hamilton, Animal Life in Africa (London, 1912), p,27; KNP Annual Report of the National Parks Board, 1928, p.4; 1932, p.5.

20. S-HA [Stevenson-Hamilton Archives, Fairholm, Larkhall] Diary entry 23 April 1904; Cent. LDE26 44/2. Under-Secretary to Inspector of Lands, 23 May 1905.

21. In 1926 the 'respectable sum' of $£ 444$ was raised: KNP Annual Report of the Kruger National Park, 1928, p.6.

22. KNP Opsienersjaarverslae, vol.2, Annual Report of the Warden, Kruger National Park, 1930.

23. TA TPS\& Annual Report of the Sabi and Singwitsi Game Reserves for 1920, p.3.

24. KNP Rangers' Diaries, Section 4, June 1936. pp.I-2.

25. KNP Annual Report of the Kruger National Park, 1939 , p.6: in 1952, however, there were still about 1200 people - described as 'woonkaffers' - living in the Kruger National Park, although most of them were probably park employees, Annual Report of the National Parks Board, 1952, pp.4-5.

26. TA TPB784 TA3006. Stevenson-Hamilton to Secretary to the Administrator, 15 February 1911

27. KNP Annual Reports of the Sabi and Singwitsi Game Reserves for $1912,1913,1914,1915,1916$, 1918.

28. Wits [Manuscript Collection of the University of the Witwatersrand] A839, H.E. Schoch Papers, Db3, 30 July 1923.

29. Cent. JUS385 3/651/23, Barberton Magistrate to Secretary for Justice, 21 October $1923 ;$ KNP K42 KNP28/2, Deputy Commissioner to Warden, 16 September 1938; Cent. NTS 1654 130/274, Inspection Report, 24 August 1932; Controller and Auditor General to Stevenson-Hamilton, $6 \mathrm{Au}$ gust 1940; Cent. JUS2943/710/20, Secretary for Justice to Provincial Secretary, 24 September 1920.

30. Wits A839, H.E. Schoch Papers, Db3, 30 July 1923.
31. KNP K42 KNP28/2. Warden to Commissioner. 5 June 1924; Commissioner to Warden, 24 June 1924.

32. KNP Opsienersjaarverslae, vol. 2, Annual Report of the Warden. Kruger National Park, 1929; KNP KNP28/2, Station Commander Skukuza to Assistant Native Commissioner Skukuza, 4 November 1941.

33. Braack, Kruger National Park, p.16.

34. S-HA Diary entry 23 July 1902.

35. KNP Rangers' Diaries, 1940.

36. KNP Annual Report of the Sabi and Singwitsi Game Reserves for 1911, p.3.

37. Trapido, 'Poachers, proletarians and gentry', p,20.

38. KNP Rangers' Diaries, Section 2, 1941, p.1.

39. KNP K15 KNP3, Warden to all Rangers, 30 October 1937; KNP Annual Report of the National Parks Board, 1928, p.2: KNP Annual Report of the National Parks Board, 1931, p.2; KNP Annual Report of the National Parks Board, 1935 , p.4; S-HA Diary entry 30 January 1946; KNP Newspaper cutting book I, 1945.

40. Transvaal Province, Report of the Game Reserves Commission, TP5-18 (Pretoria, 1918) p.9; TA TPS8 TA3072, Acting Provincial Secretary to Acting Warden, 16 July 1917.

41. A recent popular source infers that without taking away territory from the Tsonga, there would have been no Kruger National Park: see Koch, et al, Water, Waste and Wildlife, p.17.

42. For details of the history of the Makuleke and their removal from the Pafuri area see P. Harries, 'A forgotten corner of the Transvaal: reconstructing the history of a re-located community through oral testimony and song', a paper presented at the History Workshop, University of the Witwatersrand, 1984.

43. KNP Annual Report of the Sabi Game Reserve, 1905, item B57: TA TPS8 TA3072, Acting Secretary for Native Affairs to Provincial Secretary, 1 April 1912; TA TPS8 TA3075, Annual Report of the Sabi and Singwitsi Game Reserves for 1913; TPS8 TA3072, Acting Secretary for Native Affairs to Assistant Colonial Secretary, 16 May 1908.

44. KNP Annual Report of the National Parks Board, 1932, p.5.

45. Cent. NTS 2527 147/293 I, 1910-1911; NTS 3589 $853 / 308$, 1930-1939; NTS 7612 8/329, 1922; KNP Minutes of the National Parks Board of Trustees, 1933; S-HA, Diary entry, 30 July 1933.

46. S-HA Diary entry, 20 May 1933; TA SNA 392 4321/07; Cent. NTS 76/6 17/329, Assistant Native Commissioner Sibasa to Native Commissioner Louis Trichardt, 24 July 1933.

47. KNP Minutes of the National Parks Board. 19 March 1933; 3 May 1938; 11 May 1938; K1/7.9. 10. Warden to Secretary National Parks Board, 30 October 1948.

48. 'Verslag oor 'n ondersoek van die bestuur van die verskeie nasionale parke en die Nasionale 
Parkeraad se administrasie', September 1952, p.136(Hoek Report); KNP K7/6 K7/7, Van Graan to Chairman and members of the National Parks Board, 31 March 1950. The Pafuri incident occurred at about the same time that a strong white agricultural lobby was able to overturn legislation which had established a wildlife sanctuary in the north-western Transvaal: see, E.J. Carruthers, 'The Dongola Wild Life Sanctuary: "psychological blunder, economic folly and political monstrosity" or "more valuable than rubies and gold"?', Kleio, 24, 1992.

49. KNP S. Joubert, 'Masterplan for the Management of the Kruger National Park', 1984, p.136-137.

50. Harries, 'Forgotten corner', pp.9-13.

51. The Association's overt and extreme selfishness eventually jarred with the colonial authorities which had been influenced by growing international protectionist concerns and defended the internationally-held position that traditional African hunting practices were not very detrimental. The colonial government even averred that the best hunting in the Transvaal was to be found on African-owned land.In 1902 the new Transvaal colonial administration introduced wildlife protection legislation in which black landowners were treated equally with whites. This was abhorred by the Transvaal Game Protection Association which predicted that wildlife extinction would result: TA CS396 10370/03, TGPA to Colonial Secretary, 18 November 1903. In 1907, after the awarding of responsible government, the Transvaal legislature succeeded in overturning this ordinance. In addition, over-enthusiastic trout fisherman were responsible for a law prohibiting the catching of any species of fish in the Transvaal between May and September each year, thus depriving rural people of protein subsistence during the winter months. It took two years for the hardship that this law created to be borne home to the lawmakers and only in 1906 did Ordinance 5 restore the legality of catching certain indigenous fish species throughout the year: TA SNA305 NA1 1/6, Commissioner for Native Affairs to Secretary of Native Affairs, 11 January 1906; TAD405 G946/06, Assistant Colonial Secretary to TGPA, 23 January 1906 . See also TA SNA305 11/06, Assistant Colonial Secretary to Secretary for Native Affairs, 30 December 1905.

52. Penalties were African poaching was harsher than for whites, for instance, a black hunter who had killed a duiker received a month's imprisonment with hard labour without the option of a fine, while a group of three whites who had killed four reedbuck, two duiker, a steenbuck and a korhaan, were sentenced to a fine of $£ 5$ or seven days' imprisonment; TA LD784 TA3006, Note to Colonial Secretary, 15 February 1909; KNP Stevenson-Hamilton Documents in Trust, List of cases
(Natives), 1903, 1 February 1903; March 1903; 18 March 1903; 27 March 1903; KNP Rangers' Diaries January 1936, Section 3.

53. KNP Rangers' Diaries, Section 3, March 1936; Section 4, January 1938.

54. TA TPS8 TA3075, Annual Report of the Sabi and Singwitsi Game Reserves for 1913, pp.4 and 10; KNP Rangers' Diaries May 1936, Section 2, p.1.

55. TA TPS8 TA3075, Annual Report of the Sabi and Singwitsi Game Reserves for 1918, p.2.

56. J. Berger, Wildlife Extension - A Participatory Approach to Conservation: A Case Study Among the Maasai People of Kenya (Ph.D., University of California, Berkeley, 1989), p.27.

57. TA SNA178 NA2536/03, Report on Singwitsi Game Reserve, 13 October 1903; TA SNA343 $3384 / 06$, C.N. Manning to Native Commissioner Soutpansberg, 4 October 1906; TA TPS8 TA3075, Annual Report of the Sabi and Singwitsi Game Reserves for 1912 and 1913; KNP Stevenson-Hamilton Documents in Trust, List of cases (Natives), 1903, 1 February 1903; 28 February 1903; 18 March 1903.

58. TA TPB784 TA3006, Stevenson-Hamilton to Secretary to the Administrator, 13 March 1911.

59. TA TPS8 TA3075, Annual Report of the Sabi and Singwitsi Game Reserves for 1913, p.5.

60. TA TPS8 TA3075, Annual Report of the Sabi and Singwitsi Game Reserves for 1912, p.5.

61. WLS [Wild Life Society of Southern Africa Archives, Pietermaritzburg] H.B. Papenfus file, Stevenson-Hamilton to Papenfus, 13 February 1926; Cent. LDE537 7748/1, vol. 1, Stevenson-Hamilton to Reitz, 12 April 1922, Stevenson-Hamilton to Sommerville, 12 April 1922.

62. H.H. Curson and J.M. Hugo, 'Preservation of game in South Africa', South African Journal of Science, 21 (1924), p.401.

63. See J. Carruthers, 'Creating a national park, 1910 to 1926', Journal of Southern African Studies, 15(2), 1989, pp.188-216.

64. A good example of this can be found in R. Knobel, 'The economic and cultural values of South African National Parks', in I. Player, ed., Voices of the Wilderness (Johannesburg, 1979).

65. KNP Joubert, 'Masterplan', p.96.

66. Hoek report, 1952, p.12.

67. KNP Minutes of the National Parks Board, 4 April 1934, item 24.

68. KNP Minutes of the National Parks Board, 19 September 1949, item 3.

69. Berger, Wildlife Extension, pp.33-36.

70. A concession for pastoralists in the Richterveld National Park was won after pressure was exerted on the National Parks Board; see J. Cock and E. Koch, eds, Going Green: People, Politics and the Environment in South Africa (Cape Town, 1991), pp.112-128. 